\title{
International Repatriations of Indigenous Human Remains and Its Complexities: the Australian Experience ${ }^{1}$
}

\author{
Paul Turnbull
}

\begin{abstract}
Over the past forty or so years, many Indigenous peoples in former settler colonies have fought for, and in many instances won, recognition of their rights to have the bodily remains of their ancestors returned from Western museums and other scientific institutions for burial. It has been a remarkable achievement. However, as this article highlights, in the Australian context, the efforts of Aboriginal peoples and Torres Strait Islanders to secure and bury the remains of their ancestors as their cultures require have, in many cases, been complicated by challenges arising from the need to revitalize or re-establish continuities with the ancestral past eroded by settler colonialism, while seeking restoration of their ownership rights in respect of land and cultural heritage in the contemporary Australian context.
\end{abstract}

Key words: Australia; Aboriginal People; Torres Strait Islanders; Human Remains; Repatriation.

The repatriation of ancestral human remains from overseas scientific institutions by Australian and other Indigenous peoples in post-settler societies has been an extraordinary achievement. In the Australian context, tireless campaigning by Indigenous community leaders, representative organizations and activists from the mid-1970s to the late 1990s has seen Aboriginal people and Torres Strait Islanders gradually win wide public and government support for the unconditional repatriation of the remains of their ancestors from overseas scientific collections. Even so, numerous communities have found the tasks of reclaiming the dead and burying them in their ancestral country - as religious beliefs and customary law requires - difficult obligations to fulfill. It has meant complying with Australian federal government mandated arrangements for identifying ancestral remains in overseas museums and other medico-scientific collections, for negotiating their repatriation, and for returning them to community care. Since the early 1990s, claimant communities have additionally had to cope with changes to repatriation policies and programs as successive federal governments have sought to reduce public sector funding. Reclaiming the dead has proven difficult and stressful for numerous communities because of having lost ancestral land in which to bury the dead as ancestral traditions dictate, and through rendering claimants painfully mindful of the extent to which their traditional lifeways and culture were eroded or lost through colonial subjugation. Moreover, in numerous instances the dead have challenged the living by their return. Their return has in many instances provoked questions concerning rights and responsibilities to the dead, notably within communities for whom their burial within ancestral land first requires regaining its ownership through the complex framework of Australia's current national and state land laws.

Within the confines of this article, I discuss and reflect on what seem to me salient aspects of the Indigenous Australian experience of repatriation over the past thirty or so years. I do so from the perspective of a historian who in this time has undertaken research aiming to establish the provenance of remains acquired in Western scientific institutions on behalf of Indigenous Australians and their representative organizations. I have also worked with curators of anthropology and comparative anatomical collections in Australian and overseas museums on the identification of human remains in their possession, and, in recent times, as a consultant researcher for the Australian government's International Repatriation Program. Readers will find that references to sources substantiating various claims made 
in respect of repatriation and its complexities have been provided; but in the course of this article, I have drawn on first-hand knowledge of the challenges that claimant communities have faced. This may strike some readers as allowing advocacy to intrude on what should be impartial observation and reflection; but not, I hope, to the point of devaluing this effort to highlight several aspects of the Australian experience of repatriation that arguably deserve greater consideration than they have so far gained in public discourse.

\section{Where Are Our Old Ones Now?}

Until the early 1990s, Indigenous Australian communities had limited support in confirming the existence of the bodily remains of their ancestors in overseas museums, medical schools and other scientific institutions. In some communities, accounts of the plundering of traditional burial places through the course of the nineteenth and early twentieth centuries had passed from generation to generation (Turnbull 2017: 339-41). However, with few exceptions, retellings of these outrages had become factually vague if haunting memories. In some communities, thefts of the dead were forgotten; but when other communities, starting in the mid-1970s, began seeking the return of the dead known to have been acquired for museum and medical school collections, this understandably prompted others to ask whether the remains of their ancestors had also been obtained. In both cases, community members sought with what help they could get from Indigenous representative organizations, activists and sympathetic non-Indigenous university-based researchers, to learn what they could about the theft of remains and their subsequent fate.

My own involvement in repatriation research began in late 1988, after I was approached by Monty Pryor, a man of the Juru people, a senior Elder of the Birri Gubba Nation, and a Deacon of the Roman Catholic diocese of Townsville. Mr Pryor wanted help in locating the remains of his people taken from burial places in the Bowen region of North Queensland. He had learnt from books and articles held by the library of Townsville's James Cook University that Amalie Dietrich, a German naturalist, had not only collected flora and fauna specimens for Hamburg's Godeffroy Museum, but had also removed skeletons and skulls from Birri Gubba burials, and from those of the Darumbal people in Central Queensland. One of these sources, fantastically, alleged that Dietrich had actually sought to have an Aboriginal man shot for his skeleton (Roth 1908: 81).

Bodily remains of Birri Gubba people had indeed been acquired by the Godeffroy Museum (see Sumner 1993; also Scheps 1994). However, after Johann Cesar VI Godeffroy, the museum's founder and patron, was bankrupted in 1878, they were sold by a Hamburgbased ethnographic dealer to the Grassi Museum for Ethnology in Leipzig. (Sumner 1993; Scheps 1994) There, they were said to have been kept until they were destroyed during the Second World War (although recently it has been suggested to me by German colleagues that some non-European human remains collected in colonial contexts are held by the Anatomy Department of Leipzig University). Mr. Pryor naturally wanted to know whether the remains of his people had in fact been destroyed. He was also concerned to determine whether there had been other instances of the plundering of Birri Gubba burials.

\section{The ATSIC Years, 1989-2005}

By the late 1980s, numerous Indigenous communities and organizations representing their interests were asking the same questions but they had few means of gaining answers until the establishment, by the Australian Government in 1990, of the Aboriginal and Torres Strait Islander Commission (ATSIC). The Commission was a major reform of the administration of Indigenous affairs. It came into being after a lengthy consultation process and despite vigorous opposition by conservative politicians and commentators. ${ }^{2}$ ATSIC was charged with promoting Indigenous self-management and self-sufficiency by advising all levels of government, advocating the recognition of Indigenous rights regionally, nationally and internationally, and administering many of the Australian Federal Government's Indigenous programs and services. 
Soon after taking office, ATSIC's first regionally elected Commissioners were approached by several prominent community leaders and organizations wanting to secure the return of ancestral remains. Especially influential in this respect were leading figures in the Tasmanian Aboriginal Centre (TAC), and the Brisbane-based Foundation for Aboriginal and Islander Action (FAIRA). Both organizations had been active since their foundation, in 1973 and 1977 respectively, in campaigning for the repatriation of remains held in Australian museums and university medical schools. Together, FAIRA and the TAC were instrumental in persuading Australian-based museum professionals and researchers in the natural and social sciences to recognize the unconditional rights of Indigenous Australians to have the remains of their ancestors returned for burial. And by the mid-1980s, they had begun seeking the return of remains from overseas scientific collections, focusing in the first instance on securing repatriations from London's Natural History Museum, the Royal Colleges of Surgeons of England, Edinburgh and Ireland, and the Anatomy Department of Edinburgh University (Merrie et al. 1989). Between them, these institutions then held the remains of around 1,000 individuals from communities all over Australia. Delegations led by Bob Weatherall, then Director of FAIRA, and Michael Mansell, then chairperson of the TAC, did not persuade the leaders of these institutions to agree to repatriation and several were unwilling to provide information about their collections, provoking accusations that they were reluctant to have it known publicly that remains had been acquired in contexts of violent injustice (Merrie et al. 1989; Mansell 1990). Even so, the charge that science had been the beneficiary of Indigenous dispossession and colonial oppression contributed greatly to public and mainstream political support for repatriation in the United Kingdom, Ireland and Australia.

In order to establish the provenance of remains held in UK and other European collections, FAIRA began compiling a database of information in relevant scientific publications and other publicly available sources. Researchers were employed on a casual basis first with FAIRA's recurrent government funding for cultural projects, then with funding from ATSIC cultural programs between 1997-2001. ${ }^{3}$ The database opened a window onto a complex historical landscape, disclosing how separate yet often overlapping networks of collectors, scientists and institutions in different European cities with diverse research aims acquired and investigated the bodily remains of Indigenous Australians. Scientific collecting and analysis of remains began in the last decade of the eighteenth century and continued until as late as the early 1980s (Fforde 2004). Such was the longevity and extent of metropolitan medicoscientific interest in Australian remains that neither FAIRA, ATSIC, nor government agencies which were subsequently charged with securing their return found they had either funding or personnel to do more than focus on documenting the provenance of remains on the largest anatomy and anthropological collections in the United Kingdom.

In 2003, the Australian Government adopted a policy of actively seeking the unconditional return of ancestral remains via inter-government agreements (OEA 2009). ATSIC gained funding to assist communities in repatriation negotiations and enable them to follow culturally appropriate procedures for their return and reburial. Agreements with the British and soon other European national governments to assist repatriations from publicly funded museums and medical collections saw many of the latter provide information about what they held. Generally, they provided copies of entries in accession registers which, in general, briefly described remains, gave the dates when they entered the collection and, in many instances, the names of their donors. As colleagues and I have argued elsewhere, this information has proved to be of great value, but often it has been just the starting point for historical research locating further information of crucial importance to claimant communities which, in many instances, has been found in other archives and research libraries (Fforde et al. 2015), and in a variety of publications by collectors and researchers whose involvement in the acquisition of remains for particular institutions has not always been obvious from registry information provided by holding institutions.

\section{Repatriations After ATSIC}

In mid-2005, the Australian Government abolished ATSIC, arguing that in its fifteen-year history it had provided inadequate policy advice and ineffective service delivery to Indigenous 
Australians. ATSIC certainly had its failings, but the decision to abolish rather than reform the Commission was due to its having developed policies on Indigenous land entitlements and various other matters in respect of self-determination that were unacceptable to the politically conservative government then in power (see Behrendt 2009). International repatriation and other programs administered by ATSIC were transferred to a newly created portfolio under an Office of Indigenous Policy Coordination (OIPC), which initially sat within the Department of Immigration and Multicultural Affairs. By the end of 2005, OIPC and its programs had been moved to the Department of Families, Community Services and (now) Indigenous Affairs thereafter generally referred to by its cumbersome acronym, FaHCSIA.

These post-ATSIC arrangements had little support within government circles beyond politicians who applauded the Commission's abolition and the return of Indigenous policy development and programs to direct government control. Communities seeking the return of their ancestors now found that non-Indigenous bureaucrats were assigned to hold repatriation negotiations with holding institutions. Under ATSIC, this had been regarded as the sole preserve of Elders or other duly authorized community members. There were also instances in which communities were dismayed and angered by what they regarded as insensitive bureaucratic pressure to finalize community planning for the return of remains. In 2014, for example, I was shown correspondence sent by FaHCSIA staff to Ngarrindjeri Elders in 2005-6 which the latter read as forcing them to leave aspects of the return and reburial of their ancestors unresolved so as to fall into line with a timetable, set without consultation, for the repatriation of their own and other communities' ancestors. Privately, civil servants assigned to the program spoke to me of their frustration that the program's budget fell far short of what was required for them to respond to community concerns. They were also upset by becoming the target of public criticism by Bob Weatherall, Michael Mansell and other seasoned repatriation campaigners, who accused them of ignoring and disrespecting traditional cultural protocols to the point that claimant communities and their representative organizations had no option but to return to the pre-ATSIC days of independently seeking to negotiate repatriations from institutions despite having few or no resources to do so.

OPIC responded to mounting dissatisfaction by implementing a new strategy for international repatriations in November 2005. Central to the strategy was the Department of Foreign Affairs and Trade (DFAT) assisting FaHCSIA. Staff of Australia's embassies and missions were tasked with supporting the department's International Repatriation Program by approaching relevant foreign government ministries to determine the presence and origins of remains in museums and university medical schools under their control, and take initial steps in negotiating for their return. However, little progress was made, which in turn had the effect of diminishing the Program's capacity to fund and otherwise assist communities in reclaiming their ancestors, as well as limiting its ability to negotiate for title or access to land for reburial or keeping places. So much so that the Program could not spend its annual budget (despite the fact that it was widely regarded as inadequate for successfully pursuing the program's goals). Moreover, prominent Indigenous community leaders and representative organizations complained that OPIC's strategy had been devised with insignificant Indigenous input and, notably, had failed to restore the primary role in negotiating and managing the return of remains from overseas institutions that Elders and community organizations had had when overseas repatriations were administered by ATSIC between 1990-2005.

On its election to national government in 2007, the Australian Labour Party restored a measure of the power in policy-making and program delivery that Indigenous Australians lost with the abolition of ATSIC. However, Indigenous Australians were generally of the view that what the Labour government offered fell far short of addressing their needs and aspirations. FaHCSIA's new minister, Jenny Macklin, was sympathetic to community discontent. Among other initiatives, she convened an Indigenous National Repatriation Summit in November 2008, the outcome of which was the creation of an International Repatriation Advisory Committee charged with ensuring that international repatriation processes met Indigenous expectations. Minister Macklin also endorsed a government audit of the Program which began in May 2009 by examining program documentation and interviewing FaHCSIA management and program staff before meeting representatives of the Ngarrindjeri nation, Elders of the Bardi people 
and other traditional owners of the Kimberley region of North Western Australia, as well as Elders of the Anindilyakwa people of Groote Eylandt off the coast of Eastern Arnhem Land. Recognizing the extensive experience in repatriation that these communities had gained since the early 1990s, the audit team was keen to know what they saw as the International Repatriation Program's strengths and (importantly) weaknesses (OEA 2009). The audit also interviewed personnel of other public agencies and institutions, including, importantly, staff of the National Museum of Australia, who since the early 1990s had been given responsibility for keeping remains returned from overseas, either until such time that their community of origin was ready to arrange their reburial or, in the case of unprovenanced remains, until consensus could be reached as to their final resting place.

The audit found that repatriation negotiations were well managed but had fallen far short of the core policy objective adopted in 2005 of creating a comprehensive inventory of remains held by overseas institutions. The Program was also found to be inefficient in forward planning repatriation negotiations and giving communities accurate information about the number, location and provenance of returning remains (OEA 2009). When the audit was conducted, the sum of what the Program knew about Indigenous remains in continental collections was little more than could be found in Carol Cooper's Aboriginal and Torres Strait Islander Collections in Overseas Museums (Cooper 1989). Cooper had itemized collections in over 170 museums and several private collections in thirty countries but reportage of the presence of human remains was incidental to her prime focus on documenting Indigenous material culture in overseas collections. What else was known about holdings of human remains was what senior FaHCSIA staff had learnt during periodic visits overseas, follow-up contacts by Australian Embassy staff and several Indigenous delegations. However, in all fairness, it must be said that creating a comprehensive inventory of overseas collections has proven more difficult than the audit team assumed, notably in the cases of France and Italy.Leaders of national governments in both countries have agreed to assist the repatriation of Australian ancestral remains only to have prominent museum professionals and senior bureaucrats in their respective cultural ministries oppose repatriation on scientific, legal and ethical grounds (Turnbull 2020). In other instances - Poland, the Czech Republic, and Hungary - legislation currently governing the operation of museums and other scientific institutions has hindered attempts to reach inter-governmental agreements on responding to repatriation requests. Moreover, across Europe and North America, there have been various instances since the early 1990s of institutions with autonomy from government proving unwilling to return remains they possess on scientific grounds. ${ }^{4}$

FaHCSIA was dismantled in 2013. This saw the Department of the Prime Minister and Cabinet given interim responsibility for the International Repatriation Program, and then its relocation to the Ministry of the Arts, which in 2016 was folded into a newly created Department of Communication and the Arts (DOCA). Since then, the adverse findings of the 2009 audit of the Program have been addressed as best its modest staffing profile and budget over the past decade - in recent years around \$A500,000 a year - has allowed. Importantly, Indigenous civil servants with an informed understanding of the sensitivities and complexities of repatriation now manage the Program. Also, the creation of an inventory of major European collections is well advanced, and since 2014, DOCA has partnered with university-based researchers with expert knowledge of the history of collecting and scientific interests in Indigenous bodily remains to locate and identify the remains of Indigenous Australians in European collections. In the last two years, there have been substantial repatriations, notably from German museums and university anatomy departments resulting from negotiations between Program staff, Australia's Berlin embassy and government ministers of several German states. ${ }^{5}$ However, the Program's budget and staff profile has left it no practical option other than to schedule the return of remains to communities from one institution at a time. This has been a source of frustration for claimant communities. As Yawuru Elder Neil McKenzie recently observed in connection with the repatriation of remains of his ancestors from Leipzig's Grassi Museum, 'It's so disappointing that we have to be put on a waiting list when these remains, these people, should never have been taken from their home in the first place.' ${ }^{6}$ 


\section{Long and Sometimes Unfinished Returns to Country}

Currently, the National Museum of Australia securely houses the remains of over 700 Indigenous Australians. Most have been returned from overseas collections. Many have little or no known provenance beyond attribution to Australia, or one of its states or territories. ${ }^{7}$ They will stay in the care of the museum until such time that the Australian Government elects to create a national resting place as its Indigenous repatriation advisory group has recommended after successive rounds of community consultation over the past decade. Indeed, the creation of a national resting place seems increasingly likely. In November 2019, the Department of Prime Minister and Cabinet commissioned the Australian Institute of Aboriginal and Torres Strait Islander Studies (AIATSIS) to undertake a scoping study to advise government on the requirements in terms of size, cultural needs and possible research and educational functions of a resting place.

The question of how many individuals' remains might ultimately come to lie in a national resting place, however, has become somewhat complicated in recent times by claims that the community of origin of unprovenanced remains might be identified by current or projected advances in genomic mapping techniques. Recently, there have been several Australian university-based projects focused on extracting and matching DNA samples, obtained from living subjects, with bones discovered during archaeological digs or exposed inadvertently by human activity or through erosion, and also from bones and hair samples long held in museum collections. A number of scientists engaged in this research confidently maintain that comparative studies of genes have the potential to identify long-term connections to land and also the likely community of origin of unprovenanced remains in museums (see Wright et al. 2018; Phillips 2019). However, as other experts in genetics have warned, there is good reason to be cautious about the potential contribution of genomic mapping to repatriation. Remains with poor or no provenance in Australia and overseas collections are often likely to be in physical states making it impossible to recover enough DNA for comparison with samples obtained from the remains of known individuals, or from saliva or blood provided by living subjects. There is also the divergence of biogenetics and social genealogy caused by histories of changes to traditional practices and beliefs in respect of sex, marriage and family structures in many communities wrought by settler colonialism. Hence there is no guarantee that comparing DNA from living individuals with that which might be extracted from bones long held by scientific institutions might not erroneously posit the existence of familial or communal ties between the living and the dead on the basis of genetic signatures (Collard et al. 2019).

This is not to deny that genomic mapping, if used in combination with isotopic analysis and anthropological and historical research, might enable the repatriation of currently unprovenanced remains to their community of origin (Collard et al. 2019). And whereas until quite recently there was general opposition to ancestral remains being subjected to any further scientific scrutiny, some communities (to date notably in Northern Queensland) have begun collaborating with geneticists in the hope of establishing familial connections to unprovenanced bones in museums (Wright, et al. 2018; Phillips 2019). Also, there are communities that have proven willing to explore whether DNA analysis can identify family members buried in rural cemeteries over the past hundred or so years now at risk of erosion. ${ }^{8}$ However, as anthropologist and ethicist, Emma Kowal, has judiciously observed of this shift in attitude in respect of biogenetic technologies, it is vital that Indigenous Australians have accurate and impartially presented information as to the possible benefits and also the limits of what genomic mapping can offer. This is especially so given that it has the potential to encourage families within communities, wherein there is conflict over claims to land made within Australia's Native Title framework, to assert ownership on the basis of biological, not social, descent (Kowal 2012; Kowal 2015; Watt et al. 2020).

\section{Where Do We Bury Them?}

Since the early 1990s, there have been numerous instances of communities experiencing difficulties in reburying remains returned from overseas collections. The first and most commonly experienced problem has been the lack of title to land in ancestral country to bury the dead as customary law demands. Settler colonialism has been fundamentally a 
contest for land. As Patrick Wolfe observed, given that 'land is necessary for life...contests for land can be - indeed, often are - contests for life' (Wolfe 2006: 387). The foundation and growth of Australian and comparable settler societies between 1760-1900 entailed the dispossession of Indigenous peoples. In the Australian context, the many societies inhabiting South-Eastern Australia had, by the late 1840s, been deprived of their land and the capacity to maintain their traditional lifeways, more often than not by indiscriminate settler violence. Some communities continued to live on their ancestral country when pastoralists required their labour. Otherwise they were removed to 'protective' reserves administered by colonial authorities or missionaries whereon they were subjected to regimes bent on achieving their conversion to Christianity and the destruction of ancestral languages, lifeways and cultures (Tatz 1999; Dwyer and Ryan 2016). Much the same history of violent dispossession and colonial subjugation played out in Northern Queensland from the 1860s and in the north of Western Australia from the 1880s. In both of these vast regions, its peoples, who were deemed surplus to the requirements of pastoralism, mining and the northern pearling industries, were corralled on 'protective' Church and Government reserves (Loos 1982; May 1994; Owen 2016). By the early twentieth century, only those peoples living in remote regions of Northern and Central Australia, which proved incapable of sustaining pastoralism or other forms of economic exploitation, did not experience the wholesale theft of land and continue to speak their languages and give expression to their cultural and religious beliefs, albeit in attenuated and evolved forms. Even so, in the eyes of settler society, these peoples were imagined to have neither legal nor moral entitlement to continuing ownership and enjoyment of their ancestral lands (see Reynolds 1987; McHugh 2004).

It was not until 1992 that Indigenous Australians' continuing entitlement to possession and enjoyment of their ancestral country was recognized in Australian law ${ }^{9}$ - rights that implicitly included common law protection of land customarily used for burial (Turnbull 2017: $312-5 ; 341-3$ ). However, since the passage of legislation the following year, communities have been required to apply to Australia's Federal Court to have their traditional title to lands and waters assessed by a National Native Title Tribunal. ${ }^{10}$ The onus is thus on applicants to prove that they have continuously exercised their traditional rights and interests in land and waters, which of course many people whose families were forced onto reserves and missions away from their ancestral country - as occurred in south-eastern Australia, Tasmania, the south of western Australian, Queensland and economically exploitable regions in the north of the continent - have often found impossible to factually demonstrate to the satisfaction of the Federal Court. Also, since 1993, state and territory governments have routinely challenged the evidence that claimants have presented to the Native Title Tribunal as proof of ongoing connections to country (Farrell et al. 2007). What is more, those claimants who have been able to prove continuity of connection have found that the law allows them exclusive possession only of land and waters that continue to be unallocated Crown land, or (rarely) previously granted to Indigenous people. Further, the law holds that existing non-Indigenous property rights can extinguish native title, or allow its co-existence with non-Indigenous property rights as, for example, has been judged to be the case in respect of leases held by pastoral companies in the northern Kimberley Region of Western Australia and Cape York in Far North Queensland.

The predicament of communities entangled within Native Title processes has been incisively characterized by Franchesca Merlan. 'After all these decades of non-recognition and, indeed, state attempts to erase Indigenous relations to land,' Merlan writes,
... one might ask: why should recognition depend on the capacity for land courts and tribunals, and Indigenous and other participants, to produce collectively what is essentially an 'as if' story: we (in a position to decide these things) accord you (Indigenous people) recognition to the extent you can show you are traditional in your relations to land? To call this an 'as if' story is not to dismiss the relevance of places and the land in Indigenous people's lives, but to recognise the basically anachronistic nature of the demand being made of them (Merlan 2006: 86).

Indeed, the demands on many communities to demonstrate their 'traditionality' have left some so disadvantageously entangled in 'white fellah' law that even those with what one would think are easily demonstrable living connections to country have found it easier and often more 
advantageous to directly negotiate rights to use their ancestral lands and waters for cultural and economic ends with non-Indigenous property holders (Russell 2005).

Since the early 1990 s, various communities with indisputable connections to repatriated ancestral human remains have found it difficult, or impossible, to gain suitable legal bestowal of land in which to bury them, or on which to erect a resting place in which they can safely be kept. In 1991, for example, the remains of Kannabi Byugal, a man who led resistance to the invasion of the lands of Dhawaral and Gundungurra people to the southwest of present-day Sydney were returned from the Anatomy Department of the University of Edinburgh in 1991 (Pickering 2010). Since that time, Kannabi Byugal's direct descendants have lobbied the New South Wales Government with the help of a local member of parliament for ownership of Crown land believed to be where he and families of his clan were ambushed and killed by a military detachment in 1816. To date, a parcel of land has been granted for a memorial, but there is as yet no consensus among Kannabi Byugal's descendants as to whether this or some other portion of unreclaimed traditional country should be the place where his remains should be buried. Similarly, the Juru people of North Queensland's Birri Gubba Nation were prevented for near eighteen years from burying remains returned from Australian and overseas collections in the early 1990s, as their customary law demanded, in groves of Burdekin Plum Trees within and adjoining what is now Cape Upstart National Park between Bowen and Townsville. It took that long to achieve a mediated settlement in the Native Tile Tribunal between the Juru people, the Queensland Government and non-Indigenous title holders. ${ }^{11}$

Not having land in which the dead can be appropriately buried is not the only difficulty that communities have experienced over the past near thirty years. In 1994, for example, the embalmed remains of a Manbarra man named Kukamunburra, whom Europeans called 'Tambo', were returned to Palm Island, off the coast of Northern Queensland, from Cleveland in the USA, where he had died in 1884 (see Poignant 2004). Since 1918, Palm Island has been home to peoples forcibly removed by the Queensland Government from various parts of North and Northwestern Queensland. In many instances, families of different tribal ancestry have inter-married for three to four generations. Kukamunburra's return raised concern within the island community that his Manbara descendants would use his burial in country to initiate a native title claim on the Island. However, Walter Palm Island, a direct descendant of Kukamunburra and senior lawman of the Manbarra people, sought to re-assure Elders of peoples whose ancestors were exiled to Palm Island from the mainland that the Manbarra merely wished to have their ancestral ownership and cultural authority respected. Despite dissent voiced by members of the Wulgurubaka of the coastal region to the south of the Island, the Palm Island community agreed to the Manbarra's performing the ceremonies accompanying his burial in an event that brought together a community long riven by disputes over the governance, provision of services and employment on the island. However, as Walter Palm Island later conceded, the harmony achieved at the time of the burial of his ancestor, 'could never be maintained at that level indefinitely' (see Palm Island 2002: 227). Indeed, Kukamunburra's return continues to be a source of tension in this fractured community and, as such, underscores that the return of the dead can provoke diverse responses, especially in communities in eastern Australia which were dispossessed of their country in the early decades of colonization and long confined to government or Church-administered settlements. As Katherine Lambert-Pennington observes in writing of the return of the remains of twentyone people to the La Perouse community of Southern Sydney in 2002,

Not unexpectedly they [repatriations] can generate conflicting discourses among Aboriginal people as well as among researchers and within government agencies. On one hand, these acts [of repatriation] have transformative potential - for State-Aboriginal relations, for community structures and social relations, and for Aboriginal recognition. On the other hand, the return of skeletal remains to Aboriginal communities, particularly ones in settled urban areas like La Perouse, raises important questions about Aboriginal representation, history, knowledge, and cultural practices (Lambert-Pennington 2007: 314). 
This said, the obligation to repatriate and bury the dead has rarely been questioned even though it has painfully reminded many claimant communities of the unresolved psychic and material legacies of colonialism (Atkinson 2010).

Repatriations can also threaten to rekindle disputes in communities that have remained in possession of their ancestral country. An unusually vivid and well-documented example of this concerns remains acquired either between 1935-7 or 1942-3 by anthropologist Donald Thomson. Elders of Yolngu clans in northeast Arnhem Land quietly gave Thompson the bones of around a dozen individuals. As I have shown elsewhere, this was not a unique instance of Indigenous complicity in scientific collecting of human remains, but its occurrence was rare (Turnbull 2017: 336-7). In this case, Thomson arranged for the safe keeping of these relics by the University of Melbourne. There they laid unexamined until the 1980s, when they were transferred, by order of Victoria's Supreme Court, to the Museum of Victoria in the wake of demands in the early 1980s by the Yorta Yorta Nation, the Dhauwurd Wurrung people and Wurundjeri and other Kulin tribes that the museum return the remains of their ancestors it had acquired through the plundering of burial places since the turn of the twentieth century (Faulkhead et al. 2010). After Bob Weatherall, the executive director of FAIRA, wrote to the museum demanding the return of these Yolngu remains to their descendant clans, the museum approached anthropologist Nicolas Peterson, who had worked with Yolngu people for many years. On raising the issue with senior lawmen of the relevant clans, Peterson was told that the remains were almost certainly those of individuals killed in disputes over land ownership (Peterson and White 1985). It seemed likely they were given to Thomson, who was remembered as an honourable man, in order to prevent recurring pay-back killings by physical means or magic. The lawmen were firmly of the view that the bones should stay in the care of the museum, declaring that this was 'Yolngu business' in which the involvement of any other Indigenous or non-Indigenous persons (FAIRA was in mind here) would not be tolerated.

\section{Conclusion}

In an essay reflecting on his participation in an Australian Government funded project of 2004-5 to return sacred ceremonial artefacts (acquired by the Museum of Victoria) to their communities of origin in central Australia, anthropologist and curator Philip Batty writes of the experience that

It would seem that repatriation is more about white redemption and the alleviation of guilt, than about whether this or that object was stolen or sold. It is more important that the process of repatriation be seen to be carried out, than to be concerned about such details. Certainly, this seems to be the view of the Australian Council of Cultural Ministers (a body made up of all state and federal arts ministers), whose only real interest is in adding up the number of objects returned by museums. In a sense, these objects can be seen as theatrical props in a wider redemptive ritual and their repatriation a symbolic act of national reconciliation (Batty 2005: 35).

Batty writes of his involvement in returning these artefacts (churingas). He does not discuss the repatriation of ancestral human remains. Even so, one is inclined to wonder whether his characterizing the motivation of Australian national and state governments in pressing for the return of churingas as redemptive ritualism arguably has some relevance for assessing how Australian Government overseas repatriation policy and processes have operated since 2003. The policy clearly enunciates the view of government that repatriation helps promote national reconciliation. And in its doing so one is drawn to reflect on what, Francesca Merlan has argued, is the failure of Australian liberal multiculturalism to confront the degree to which Indigenous disadvantage has been '...the result of expropriation and Aborigines' enmeshment in political and economic systems which [have] rendered them powerless and unequal to others.... Merlan draws attention to the tendency with liberal discourse naively to assume that Indigenous Australians '....have been deprived of what was indigenously theirs, and that this should be restored to them in what are construed as their own mytho-religious (that is, nonmarket) terms' (Merlan 2006: 101). Reflecting on Merlan's account of the limitations of liberal 
perspectives on Indigenous rights in respect of reconnection to land and cultural heritage, one is inclined to look more critically on the heavy emphasis that the Australian Government has put, since its assuming direct control of overseas repatriations, on the capacity of the return of the dead to promote healing and reconciliation by strengthening what are seen as 'traditional' Indigenous spiritual obligations to the dead. One is drawn to question whether this emphasis on the spiritual importance of repatriation - for all that it acknowledges how important this is for Indigenous Australians - has been at the expense of recognizing and responding to the complexities of repatriation born out of Indigenous entanglement within, and accommodation to, changes wrought by settler colonialism. And in this respect, we would do well to see, as biological anthropologist Colin Pardoe observed in the early 1990s, that the repatriation of ancestral remains has occurred because 'Indigenous people were demanding control, accountability and recognition of their ownership of their past. It was not something conceptualized by scholars for the good of Indigenous people' (Pardoe 1991: 17). Certainly, communities have emphasized that returning the spirits of their 'Old People' to the care of the land has strengthened self, familial and communal well-being as well as continuities of cultural life. But equally, they have generally represented the plundering of the ancestral dead in public discourse as emblematic of the experience of dispossession and captivity in political and economic systems which have required often complex and disadvantageous accommodations and relations with settler and post-settler Australian society (see Merrie, Fourmile and Weatherall 1989). Moreover, while communities have commonly acknowledged that returning the bones, and thus the spirits, of their ancestors to the care of country has brought happiness, some have conceded that it has been a catalyst for intra-communal tensions connected to factors such as the need to legally regain ownership of land in which the dead can be buried, or the need to reach consensus on who has the authority to determine and perform appropriate funerary ceremonies.

As mentioned earlier, the Australian Government commissioned a scoping study in late 2019 for a proposed national resting place for unprovenanced Indigenous ancestral remains. If the study is followed by a commitment to building a resting place, most likely in Canberra, it would be a lost opportunity were it to be symbolic of national reconciliation in ways that simplify the meanings and values of repatriation, or worse still, evoke in non-Indigenous Australians the desire for redemption and the alleviation of guilt. If there is to be a resting place, then the challenge will be to design it so as to encourage reflection on the complexities of repatriation. It should also be an institution that recognizes and assists those communities who have the possibility of reburying their ancestors, but can only do so with resources and support to resolve complications in repatriation arising from both continuities with the ancestral past and the legacies of change wrought by diverse experiences of settler colonialism.

Received:4 September 2019

Finally Accepted: 21 February 2020

\section{Notes}

1 Research on which this article draws was made possible by funding from the Australian Research Council through its Linkage Scheme (LP130100131: Return, Reconcile, Renew: Understanding the History, Effects and Opportunities of Repatriation).

2 Attorney-General's Department (1989) 'Federal Register of Legislation: Aboriginal and Torres Strait Islander Commission Act 1989' https://www.legislation.gov.au/Details/

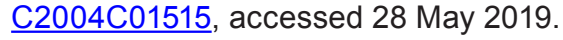

3 I also served as a consultant on the development of the database on a pro bono basis.

4 Many of these instances of opposition to repatriation are documented by contributors to Fforde, et al. 2020.

5 Department of Communication and the Arts (2019) 'Fact Sheet-International Repatriation' https://www.arts.gov.au/documents/factsheet-indigenous-repatriation-programinternational, accessed 6 January 2020. 
6 Parke, E. (2019) 'Indigenous Bones returned to Australia Century after Black-Market Trade Reveal Cruel Treatment' ABC 7.30 Report, 21 May: https://www.abc.net.au/news/201905-21/indigenous-bones-returned-from-overseas-reveal-cruel-treatment/11078792?pfm redir=sm\&fbclid=IwAR0E6JaMaRJBgwBYL2cWnKciMBbH92jSm4b2GOpWX9nOgoj45 xbF-IHyQ4M, accessed 20 May 2019.

7 Pickering, M. and Gordon, P. (2011) 'Repatriation: the End of the Beginning', in Des Griffin and Louis Paroissien (eds), National Museum of Australia: nma.gov.au/research/ understanding-museums/MPickering_PGordon_2011.html, accessed 1 August 2016.

8 Parke, E. (2018)'Fifty Skeletons Still Boxed Up After Being Exhumed from Eroding Cemetery in Fitzroy Crossing', ABC News, 25 February: https://www.abc.net.au/news/2018-02-25/ skeletons-remain-boxed-up-after-excavation-fitzroy-crossing/9473872, accessed 23 May, 2019.

9 High Court of Australia, 'Mabo v Queensland No. 21992 (Cth).' https://www.foundingdocs. gov.au/item-did-33.html, accessed 26 May 2019.

10 Native Title Act (1993), https://www.legislation.gov.au/Details/C2019C00054, accessed 26 May 2019.

11 National Native Title Tribunal (2011) 'QCD2011/003 - Juru (Cape Upstart) People' National Native Title Tribunal: http://www.nntt.gov.au/searchRegApps/NativeTitleClaims/Pages/ Determination details.aspx?NNTT Fileno=QCD2011/003, accessed 27 May 2019.

\section{References}

Atkinson, H. (2010) 'The Meaning and Values of Repatriation', in Paul Turnbull and Michael Pickering (eds) The Long Way Home, 15-9, Oxford: Berghahn.

Batty, P. (2005) 'White Redemption Rituals. Repatriating Aboriginal Secret-Sacred Objects', Arena, 23 29-36.

Behrendt, L. (2009) 'Representative Structures - Lessons Learned from the ATSIC Era', The Journal of Indigenous Policy, 10 35-63.

Collard, M. et al. (2019) 'Giving it a Burl: Towards the Integration of Genetics, Isotope Chemistry, and Osteoarchaeology in Cape York, Tropical North Queensland, Australia', World Archaeology DOI: 10.1080/00438243.2019.1686418.

Cooper, C. (1989) Aboriginal and Torres Strait Islander Collections in Overseas Museums, Canberra: Aboriginal Studies Press.

Dwyer, P. and Ryan, L. (2016) 'Reflections on Genocide and Settler-colonial Violence', History Australia, 13 335-50.

Farrell, R., Catlin, J. and Bauman, T. (2007) Getting Outcomes Sooner: Report on a Native Title Connection Workshop, Barossa Valley, Perth: National Native Title Tribunal.

Faulkhead, S., Berg, J., Russell, L., Jones, R.L. and Eades, J. (2010) Power and the Passion: our Ancestors Return Home, Melbourne: Koori Heritage Trust.

Fforde, C. (2004) Collecting the Dead: Archaeology and the Reburial Issue, London: Duckworth. 
Fforde, F., McKeown, T. and Keeler, H. (eds) (2020) The Routledge Companion to Indigenous Repatriation. Return, Reconcile, Renew, London: Routledge: forthcoming.

Fforde, C., Ormond-Parker, L. and Turnbull, P. (2015) 'Repatriation Research: Archives and the Recovery of History and Heritage', in Ruth Redmond-Cooper (ed) Heritage, Ancestry and Law: Principles, Policies and Practices in Dealing with Historical Human Remains, 39-59, Builth Wells: Institute of Art and Law.

Kowal, E. (2012) 'Genetic Research in Indigenous Health: Significant Progress, Substantial Challenges', Medical Journal of Australia, 197 (1) 19-20.

(2015) 'Genetics and Indigenous Communities: Ethical Issues', in J. D. Wright et al. (eds) International Encyclopedia of the Social \& Behavioral Sciences, 962-8, $2^{\text {nd }}$ Edition, Amsterdam: Elsevier.

Lambert-Pennington, K. (2007) 'What Remains? Reconciling Repatriation, Aboriginal Culture, Representation and the Past', Oceania, 77 313-36.

Loos, N. (1982) Invasion and Resistance: Aboriginal-European Relations on the North Queensland Frontier 1861-1897, Canberra: Australian National University Press.

Mansell, M. (1990) 'Quest for the Return of the Missing Dead', New Straits Times, 10.

May, D. (1994) Aboriginal Labour and the Cattle Industry: Queensland from White Settlement to the Present, Melbourne: Cambridge University Press.

McHugh, P. (2004) Aboriginal Societies and the Common Law, Oxford: Oxford University Press.

Merlan, F. (2006) 'Beyond Tradition', The Asia Pacific Journal of Anthropology, 7 (1) 85 104, DOI: $10.1080 / 14442210600554507$.

Merrie, A., Fourmile, H. and Weatherall, B. (1989) 'Aborigines, Archaeologists, and the Rights of the Dead, Paper to the World Archaeological Congress Inter-Congress, Vermilion, South Dakota', Brisbane: FAIRA.

OEA (2009) Performance Audit of the International Repatriation Program, Canberra: Department of Finance and Deregulation.

Owen, C. (2016) Every Mother's Son is Guilty: Policing the Kimberley Frontier of Western Australia 1882-1905, Perth: University of Western Australia Press.

Palm Island, W. (2002) 'Tambo' in Cressida Fforde, Jane Hubert and Paul Turnbull (eds) The Dead and Their Possessions: Repatriation in Principle, Policy and Practice, 222-9, London: Routledge.

Pardoe, C. (1991) 'Eye of the Storm', Journal of Indigenous Studies 2 (1) 16-23.

Peterson, N. and White, N. (1985) Skeletal Material in the Donald Thomson Ethnographic Collection: Report on Its Scientific Significance, Melbourne: National Museum of Victoria.

Phillips, N. (2019) 'Indigenous Groups Look to Ancient DNA to Bring Their Ancestors Home', Nature, 568 294-7.

Pickering, M. (2010) 'Where Are the Stories?' The Public Historian, 32 79-95, DOI:10.1525/ tph.2010.32.1.79. 
Poignant, R. (2004) Professional Savages: Captive Lives and Western Spectacle, New Haven: Yale University Press.

Reynolds, H. (1987) The Law of the Land, Melbourne: Penguin Books.

Roth, H. L. (1908) The Discovery and Settlement of Port Mackay, Queensland, Halifax: F. King and Sons.

Russell, P. H. (2005) Recognizing Aboriginal Title, Toronto: University of Toronto Press.

Scheps, B. (1994) 'Die Australien-Sammlung aus dem Museum Godeffroy im Museum für Völkerkunde zu Leipzig', Jahrbuch des Museums für Völkerkunde zu Leipzig, 40 194-209.

Sumner, R. (1993) A Woman in the Wilderness: the Story of Amalie Dietrich in Australia, Sydney: New South Wales University Press.

Tatz, C. (1999) 'Genocide in Australia', Journal of Genocide Research, 1 315-52.

Turnbull, P. (2017) Science, Museums and Collecting the Indigenous Dead in Colonial Australia, Cham, Switzerland: Palgrave Macmillan.

(2020) 'Legally Acquired? The Moral and Legal Context of Collecting Indigenous Australian Human Remains in Colonial Australia', in Maria-Teresa Milicia (ed) The Great Laboratory of Humanity: Collection, Patrimony and the Repatriation of Human Remains, Padua: CLEUP: forthcoming.

Watt, E., Kowal E. and Cummings, C. (2020) 'Traditional Laws Meet Emerging Biotechnologies: The Impact of Genetic Genealogy on Indigenous Land Title in Australia', Human Organisation 79: forthcoming.

Wolfe, P. (2006) 'Settler Colonialism and the Elimination of the Native', Journal of Genocide Research, 8 387-409.

Wright, J. L. et al. (2018) 'Ancient Nuclear Genomes Enable Repatriation of Indigenous Human Remains', Science Advances, 4 1-12.

\section{Biography:}

Paul Turnbull is an Adjunct Professor of history and digital humanities at the University of Tasmania and an Honorary Professor of history at the University of Queensland and the Australian National University. He has undertaken provenance research for various Indigenous Australian representative organizations. Paul has written on racial science and the investigation of the bodily remains of Australian and other Indigenous peoples. His recent publications include Science, Museums and Collecting the Indigenous Dead in Colonial Australia (Palgrave Macmillan 2017), and several essays in the Routledge Companion to Indigenous Repatriation (2020). He was a chief investigator on the Return, Reconcile, Renew (2013-2016) and Restoring Dignity (2018-2020) projects, both funded by the Australian Research Council. 